\title{
Above-ground Biomass Recovery in Managed Tropical Forest in the Jari Valley, Eastern Amazon
}

\author{
Adriano Castelo dos Santos ${ }^{1}$, Eleneide Doff Sotta ${ }^{2}$, Marcelino Carneiro Guedes ${ }^{2} \&$ Lilian Blanc $^{3,4}$ \\ ${ }^{1}$ Instituto Estadual de Florestas do Amapá, Macapá, Brazil \\ ${ }^{2}$ Empresa Brasileira de Pesquisa Agropecuária (Embrapa Amapá), Macapá, Brazil \\ ${ }^{3}$ Forêts et Sociétés, CIRAD, Montpellier, France \\ ${ }^{4}$ Université de Montpellier, Montpellier, France \\ Correspondence: Adriano Castelo dos Santos, Instituto Estadual de Florestas do Amapá, Macapá, Brazil. Tel: \\ 96-981-407-208. E-mail: adrianocasteloeng@gmail.com
}

\author{
Received: October 6, $2018 \quad$ Accepted: January 5, $2019 \quad$ Online Published: May 15, 2019 \\ doi:10.5539/jas.v11n6p129 URL: https://doi.org/10.5539/jas.v11n6p129
}

The research was financed by SETEC/FAPEAP (Call $N^{o}$. 002/2013 of the of Support for Research in Amapá-FAPEAP/AIRD-Guyamazon II Cooperation Bilateral FAPEAP/AIRD-2013, International Cooperation Program Between Foundation for Research Support of the State of Amapá-FAPEAP and L'Agence Interétablissements de Recherche pour le Developpement-AIRD).

\begin{abstract}
Tropical forests play an important role in maintaining the regional rainfall regime and global climate, besides representing a significant stock of carbon. This study aimed at evaluate above-ground biomass (AGB) recovery, after reduced-impact logging (RIL) in a managed forest on the Jari River valley. The data were collected in 15 plots $(100 \mathrm{~m} \times 100 \mathrm{~m})$ in the management area of the Jari Florestal Company. To estimate AGB we used a local equation adjusted for forests in the eastern Amazon. AGB before logging ranged from 157.9 $\mathrm{Mg} \mathrm{ha}^{-1}$ to 619.9 $\mathrm{Mg} \mathrm{ha}^{-1}$, with an average of $362.5 \mathrm{Mg} \mathrm{ha}^{-1}$. AGB after logging ranged from $151.2 \mathrm{Mg} \mathrm{ha}^{-1}$ to $632.8 \mathrm{Mg} \mathrm{ha}^{-1}$, with an average of $322.4 \mathrm{Mg} \mathrm{ha}^{-1}$. The time of monitoring of the plots and logging intensity were the main factors that influenced the recovery of the AGB. In 12 years after the RIL, the forest was able to recover its initial stocks of AGB, in places of low exploitation intensity.
\end{abstract}

Keywords: remaining biomass, logging intensity, reduced-impact logging

\section{Introduction}

Forests, even to produce wood (managed), exert important role in the maintenance of the regional rainfall regime and the global climate, they emit large volumes of water into the atmosphere and represent a significant carbon stock in forest biomass (SFB \& IPAM, 2011; Piponiot et al., 2016).

The recently introduced sustainable forest management (SFM) for production forests is beneficial for the maintenance of forest resources (Imai et al., 2009). The application of SFM in tropical forests increases the storage of biomass and carbon in these ecosystems. Although of the efforts of the regulatory institutions, SFM in the Brazilian Amazon continues to be performed without planning for future cutting cycles (Braz et al., 2015).

Management plans must be consistent with sustainable forest management and shall ensure the continuous production of forest products and services (Gourlet-Fleury et al., 2013). The costs associated with the planned operation are by the benefits of RIL: the reduction of the time of operation of machines and the work per cubic meter of extracted wood, reduction of wood waste and decrease of damage to the remaining trees (Jonhs et al., 1996; Sist \& Ferreira, 2007; Miller et al., 2011).

The intensity of exploitation and the cutting cycle are the main determinants of extent that forest carbon stocks may be depleted (Zimmermann \& Kormos, 2012). However, the effects of RIL on biomass loss are difficult to evaluate due to differences in cut intensity, a problem that is not widely recognized in the literature on managed forests (Martin et al., 2015). Reducing the intensity of exploitation could considerably reduce carbon emissions, favoring the recovery of biomass (Sist et al., 2014). 
A fundamental item for the SFM is the minimum cutting diameter (MCD), measured 1.3 meters high from the ground. By Brazilian standards (CONAMA Resolution 406/2009), the MCD in Amazon forests is $50 \mathrm{~cm}$ (Brazil, 2009). Sist et al. (2003) point out that only the imposition of a minimum cutting diameter limit does not guarantee the sustainability of forest management.

Exploration planning in the SFM considers some measures to protect the remaining trees: protection of the remaining trees (species of commercial trees exploited in a given enterprise that contain, at the moment of the forest inventory, a DBH below the minimum cutting diameter), matrices and trees big ones. In addition to the contribution to AGB gains, large trees are ecologically important for seed production.

In the Amazon, more than 15.000 tree species have been described, of which, 227 species are hyper dominant, representing half of the Amazonian trees whole (Ter Steege et al., 2013). Among them are the commercial species, commonly used in the region for timber production. Recent studies (Miller et al., 2011; Braz et al., 2012; Vidal et al., 2016; Rocha et al., 2017) have shown that the managed forest can not recover its stocks of wood for the second cutting cycle, while AGB substantially recovers its initial stocks.

This study aimed to evaluate the recovery of above-ground biomass of tropical rainforest after reduced-impact logging. Our hypothesis is that the forest can recover its initial stocks of AGB, depending on the intensity of exploitation in the area and the number of large trees harvested.

\section{Material and Methods}

\subsection{Study Area}

The study was conducted on the forest management area (FMA) of the Jari Florestal Company, located in the municipality of Almerim, state of Pará, Brazil, between latitudes $0^{\circ} 27^{\prime}$ and $1^{\circ} 30^{\prime} \mathrm{S}$, and longitudes $51^{\circ} 40^{\prime}$ and $53^{\circ} 20^{\prime} \mathrm{W}$ (Souza et al., 2014). The predominant vegetation in the study area is Sub Montane Dense Rain Forest (IBGE, 2012) and the predominant soils are yellow latosols and red-yellow ultisols.

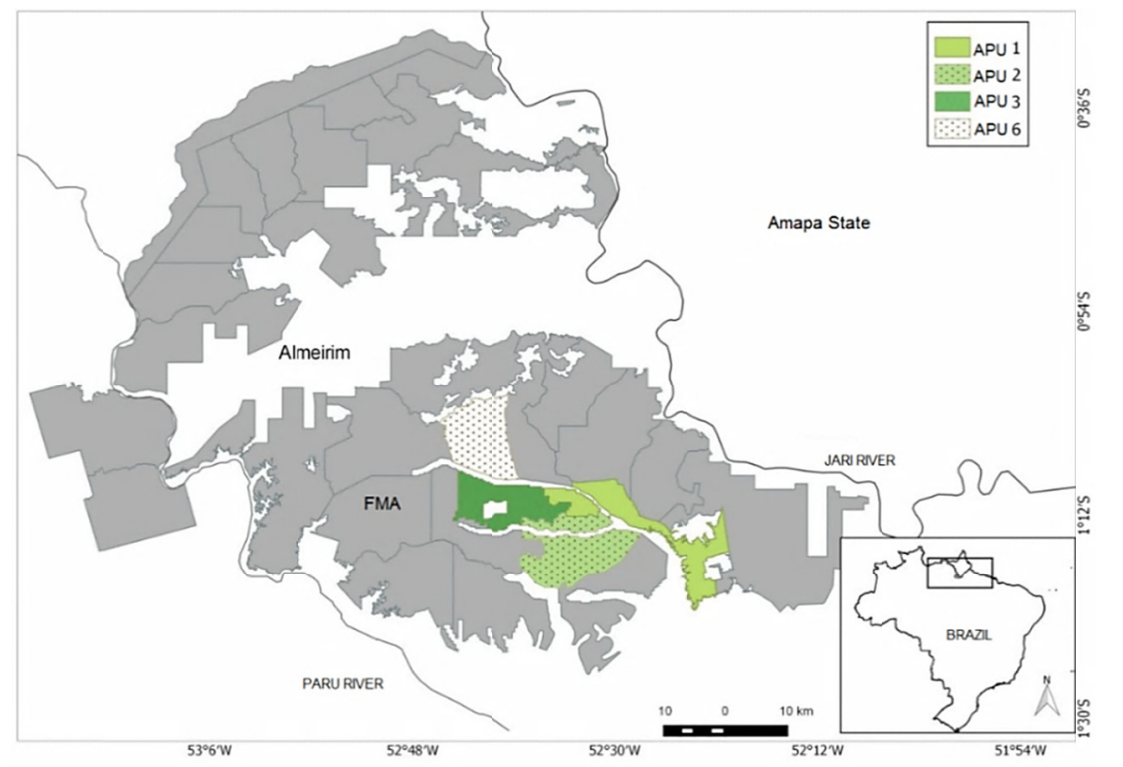

Figure 1. Location of study area

\subsection{Data Collect}

\subsubsection{Forest Inventory Data From Permanent Plots}

We used the data from permanent plots of the Jari Florestal Company S.A. forest management area. These data were collected by an inventory team, before and after reduced impact logging (RIL), which began in 2003. The plots are 1.0 ha in size $(100 \mathrm{~m} \times 100 \mathrm{~m})$ and divided into 100 subplots of $10 \mathrm{~m} \times 10 \mathrm{~m}$. In each sub-plot, trees with diameter at breast height (DBH) $1.30 \mathrm{~m}$ above the ground greater than or equal to $10 \mathrm{~cm}$ are measured. These data are collected by an inventory team, before and after the impact started in 2003 . The permanent plots were allocated (one per $200 \mathrm{ha}$ ) by lot over the work units (UTs), which are Blocks $(250 \mathrm{~m} \times 400 \mathrm{~m}$ ) within the Annual Production Units (APUs). 


\subsubsection{Field Visit}

For verification, whether or not there was exploration in the 15 plots field surveys we carried out at the MFA of Jari Florestal. We carried out two campaigns to know how many trees were harvested inside and (approximately $10 \mathrm{~m}$ away from the boundary of each plot) of the 15 plots evaluated. The first in August ( 8 field days) and the second in September 2015 (5 days).

\subsection{Data Analysis}

\subsubsection{Calculation of Above-ground Biomass}

To estimate the AGB of each tree sampled and the forest as a whole, it was used the allometric equation of Lima (2015). The AGB calculation was performed only for live trees with $\mathrm{DBH} \geq 10 \mathrm{~cm}$, before and after the RIL. The equation (Equation 1) proposed by Lima (2015) is based on a measurement scope of trees $<156 \mathrm{~cm}$ of DBH:

$$
\ln \mathrm{AGB}=-1.97256+2.44723 \cdot \operatorname{lnDBH}
$$

$$
\text { ( } R \text { adjusted, } R^{2} a j=0.96 \text {; Residual standard error, } R S E=0.437 \text {; F-statistic, } F=4958.94 \text { ) }
$$

where, AGB $=$ Dry above-ground biomass $\left(\mathrm{Mg} \mathrm{ha}^{-1}\right)$; DBH $=$ Diameter measured at height of the chest $(\mathrm{cm})$ Total AGB of trees for each plot was quantified by sum of AGBi estimate of the trees for all the trees in the 1 hectare plots, according to Fox et al. (2010):

$$
\text { Total AGB }=\Sigma \mathbf{j} \cdot \mathrm{AGB} \cdot \mathbf{i}
$$

We estimated the above-ground biomass (total AGB) in megagrams per hectare $\left(\mathrm{Mg} \mathrm{ha}^{-1}\right)$. For trees above the scope (DBH $>156 \mathrm{~cm}$ ) of the equation of Lima (2015), the AGB was calculated by extrapolation according to the methodology of Medjibe et al. (2011) and West et al. (2014).

\subsubsection{Commercial Volume Equation}

The volume of commercial wood $\left(\mathrm{m}^{3} \mathrm{ha}^{-1}\right)$ was estimated with the volume equation (Equation 2) developed for dense forests in the Amazon by Nogueira et al. (2008).

$$
\ln (\text { Volume })=\alpha+\beta \times \ln (\mathrm{DBH})
$$

where, $\alpha$ and $\beta$ are -9.008 and 2.579 for trees $<40 \mathrm{~cm}$ DBH and -6.860 and 1.994 for trees larger; DBH $=$ diameter at breast height $(\mathrm{cm})$. (R adjusted, $\mathrm{R}^{2} \mathrm{aj}=0.96$; Residual standard error, $\mathrm{RSE}=0.24$ ) for trees $<40 \mathrm{~cm}$ DBH and -6.860 and 1.994 for larger trees ( $R$ adjusted, $R^{2} a j=0.80$; Residual standard error, $R S E=0.22$ )

The rates of recovery of AGB and commercial volume were calculated with first and last measurements for each plot. The recovery percentage biomass and commercial volume, compared to that which existed prior to which was collected, was also calculated. Changes in mortality rates were calculated according to the method proposed by Sheil et al. (1995).

A Spearman correlation matrix was generated between the variables plots $(n=15)$ related to the intensity of exploitation and the rates of answers. For the most significant correlations, graphs were plotted and adjusted the linear regression models. Statistical analyzes were performed with the statistical software R (R Development Core Team, 2018).

\section{Results}

The 15 permanent plots evaluated covered 8.898 trees representing 55 families, 184 genus and 398 species. The dominant families in the forest were Fabaceae, Sapotaceae, Chrysobalanaceae, Burseraceae, Lauraceae, Moraceae and Lecythidaceae, accounting for $55 \%$ of all inventoried trees. The variation in the biomass stocks at the beginning of the 15 plots was quite significant. The plots varied from $157.9 \mathrm{Mg} \mathrm{ha}^{-1}$ to $619.9 \mathrm{Mg} \mathrm{ha}^{-1}$, with an average of $362.5 \mathrm{Mg} \mathrm{ha}^{-1}$ (Table 1). 
Table 1. AGB data before and after reduced-impact logging per plot

\begin{tabular}{lllllllllllllll}
\hline Plots & B.i & B.ex. & \%B.ex. & B.rem. & $\mathrm{t}$ (year) & $\mathrm{R}$ & $\mathrm{Rn}$ & $\mathrm{R} \%$ & $\mathrm{M}$ & $\mathrm{Mn}$ & $\mathrm{M} \%$ & $\mathrm{R}-\mathrm{M}$ & Gd & B.fi. \\
\hline P-12 & 619.9 & 0.0 & 0.0 & 619.9 & 11.5 & 3.5 & 52.0 & 0.9 & 32.0 & 60.0 & 1.0 & -28.5 & 15.6 & 632.8 \\
P-10 & 548.2 & 7.6 & 1.4 & 540.6 & 8.6 & 4.2 & 84.0 & 2.0 & 52.6 & 56.0 & 1.4 & -48.4 & 69.8 & 519.2 \\
P-01 & 496.8 & 0.0 & 0.0 & 496.8 & 7.9 & 3.7 & 57.0 & 1.7 & 71.4 & 45.0 & 1.3 & -67.6 & 98 & 466.4 \\
P-05 & 492.4 & 61.4 & 12.5 & 431.0 & 9.3 & 4.2 & 79.0 & 1.5 & 45.0 & 112.0 & 2.1 & -40.8 & 43.5 & 428.3 \\
P-08 & 466.7 & 44.5 & 9.5 & 422.3 & 9.3 & 16.4 & 213.0 & 5.3 & 15.4 & 87.0 & 2.2 & 1.0 & -47.5 & 468.8 \\
P-14 & 417.9 & 166.0 & 39.7 & 251.9 & 4.3 & 3.1 & 61.0 & 3.0 & 60.3 & 119.0 & 5.9 & -57.2 & 99 & 210.1 \\
P-06 & 360.2 & 19.0 & 5.3 & 341.2 & 4.3 & 2.9 & 58.0 & 3.1 & 114.9 & 85.0 & 4.6 & -112.0 & 201.9 & 251.3 \\
P-03 & 343.2 & 28.0 & 8.1 & 315.2 & 4.3 & 2.5 & 51.0 & 2.2 & 39.2 & 95.0 & 4.2 & -36.7 & 69.8 & 282.1 \\
P-15 & 332.5 & 59.8 & 18.0 & 272.7 & 4.3 & 3.1 & 60.0 & 2.5 & 54.8 & 88.0 & 3.7 & -51.7 & 81.1 & 243.3 \\
P-07 & 274.1 & 0.0 & 0.0 & 274.1 & 4.3 & 2.2 & 50.0 & 2.5 & 10.6 & 17.0 & 0.9 & -8.4 & -5.1 & 287.6 \\
P-04 & 269.6 & 0.0 & 0.0 & 269.6 & 11.8 & 6.5 & 117.0 & 2.0 & 33.7 & 84.0 & 1.4 & -27.2 & -13.7 & 310.5 \\
P-02 & 259.7 & 0.0 & 0.0 & 259.7 & 8.1 & 1.9 & 23.0 & 0.6 & 45.0 & 91.0 & 2.2 & -43.2 & 61.6 & 241.3 \\
P-13 & 209.3 & 0.0 & 0.0 & 209.3 & 4.2 & 3.7 & 81.0 & 3.0 & 40.5 & 58.0 & 2.3 & -36.8 & 60.7 & 185.4 \\
P-09 & 189.1 & 9.7 & 5.1 & 179.4 & 11.9 & 17.3 & 246.0 & 3.6 & 76.4 & 266.0 & 3.8 & -59.1 & 80.2 & 158.3 \\
P-11 & 157.9 & 20.5 & 13.0 & 137.5 & 11.8 & 9.4 & 163.0 & 3.3 & 30.6 & 106.0 & 2.2 & -21.2 & 7.5 & 151.2 \\
Total & 5437.5 & 416.3 & - & 5021.2 & - & 84.8 & 1395.0 & - & 722.4 & 1369.0 & - & - & - & 4836.6 \\
Average & 362.5 & 27.8 & 7.5 & 334.7 & - & 5.7 & 93.0 & 2.5 & 48.2 & 91.3 & 2.6 & - & - & 322.4 \\
\hline
\end{tabular}

Note. AGB before logging (B.i. $\left.\left(\mathrm{Mg} \mathrm{ha}^{-1}\right)\right)$, AGB logged in the plot (B.ex. $\left.\left(\mathrm{Mg} \mathrm{ha}^{-1}\right)\right)$, percentage of AGB logged in the plot (\% B.ex.), Remaining AGB (B.rem. $\left.\left(\mathrm{Mg} \mathrm{ha}^{-1}\right)\right)$, monitoring time ( $\mathrm{t}$ (year)), AGB by Recruitment (R $\left.\left(\mathrm{Mg} \mathrm{ha}^{-1}\right)\right)$, number of trees recruited $\left(\mathrm{In}\left(\mathrm{n} \mathrm{ha}^{-1}\right)\right)$, recruitment rate $(\mathrm{R} \%)$, AGB lost by mortality $\left(\mathrm{M}\left(\mathrm{Mg} \mathrm{ha}{ }^{-1}\right)\right)$, number of dead trees $\left(\mathrm{Mn}\left(\mathrm{n} \mathrm{ha}^{-1}\right)\right)$, mortality rate $(\mathrm{M} \%)$, growth or damage to the remaining trees $\left(\mathrm{Gd}\left(\mathrm{Mg} \mathrm{ha}^{-1}\right)\right)$, recruitment minus mortality (R-M) and AGB after logging (B.fi. $\left(\mathrm{Mg} \mathrm{ha}^{-1}\right)$ ).

The trees with diameter $\geq 60 \mathrm{~cm}$ of $\mathrm{DBH}, 242$ trees, with an average of 16 specimens per plot. The maximum diameter observed was $288.7 \mathrm{~cm}$, as shown in Table 2 .

Table 2. Summary of inventory data per plot

\begin{tabular}{llllllll}
\hline Plots & $(\geq 60 \mathrm{~cm})$ & $(\geq 156 \mathrm{~cm})$ & $\mathrm{S} . \mathrm{r}$ & $\mathrm{V}\left(\mathrm{m}^{3} \mathrm{ha}^{-1}\right)$ & $\mathrm{D}\left(\mathrm{n} \mathrm{ha}^{-1}\right)$ & DBHmax & DBHmed \\
\hline P-12 & 22 & 3 & 124 & 554.2 & 527.0 & 288.7 & 23.7 \\
P-10 & 25 & 2 & 89 & 507.0 & 479.0 & 286.5 & 24.4 \\
P-01 & 23 & 3 & 123 & 466.3 & 436 & 254.7 & 24.5 \\
P-08 & 7 & 5 & 104 & 396.2 & 430 & 251.5 & 22.0 \\
P-14 & 15 & 3 & 126 & 412.4 & 465.0 & 231.4 & 23.5 \\
P-05 & 21 & 2 & 127 & 521.4 & 567 & 189.5 & 24.3 \\
P-06 & 19 & 1 & 110 & 397.5 & 435 & 173.8 & 24.9 \\
P-15 & 20 & 0 & 136 & 385.4 & 562.0 & 135.0 & 22.5 \\
P-02 & 12 & 0 & 160 & 313.5 & 513 & 127.3 & 22.2 \\
P-13 & 5 & 0 & 109 & 264.7 & 593.0 & 122.6 & 20.1 \\
P-03 & 27 & 0 & 118 & 396.8 & 527 & 121.9 & 23.3 \\
P-07 & 19 & 0 & 105 & 337.8 & 464 & 114.6 & 23.7 \\
P-04 & 15 & 0 & 87 & 336.3 & 509 & 106.7 & 23.3 \\
P-11 & 9 & 0 & 106 & 196.0 & 414.0 & 102.2 & 19.7 \\
P-09 & 3 & 0 & 104 & 247.5 & 581.0 & 85.9 & 19.9 \\
Total & 242 & 19 & - & 5733 & 7502.0 & - & - \\
Average & 16 & - & 115 & 382.2 & 500 & 172.8 & 22.8
\end{tabular}

Note. Number of trees with $\mathrm{DBH} \geq 60 \mathrm{~cm}$, Number of trees with DBH $\geq 156 \mathrm{~cm}$, Species richness (S.r), Commercial volume (V), Density of trees (n), Maximum diameter (DBHmax $(\mathrm{cm})$ ) and average diameter (DBHmed (cm)).

Initial values of AGB were positively correlated with trees greater than $60 \mathrm{~cm}$ in diameter $\left(\mathrm{R}^{2}=0.38, \mathrm{n}=15, \mathrm{~F}=\right.$ $8.14, \mathrm{p}<0.01$, Figure 2). 


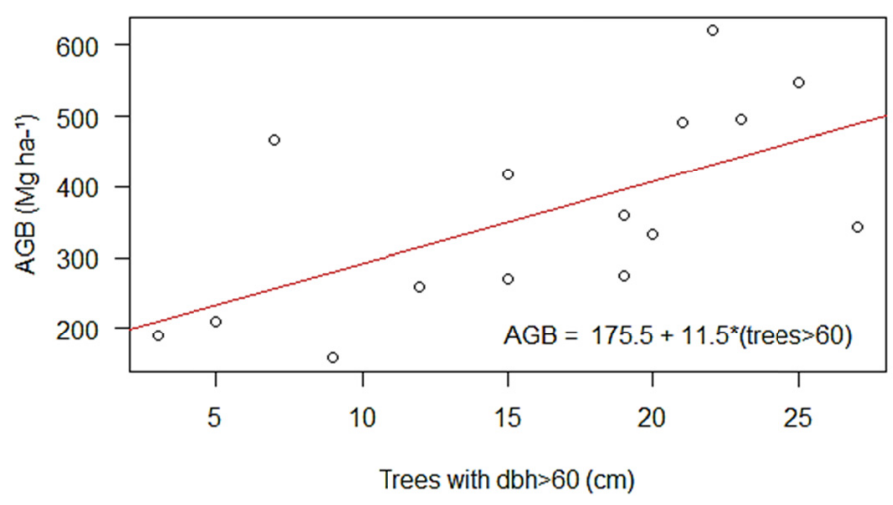

Figure 2. Correlation between large trees larger than $60 \mathrm{~cm}$ of DBH and initial AGB before reduced-impact logging

The Figure 3 shows a positive relation between the mortality rate and the percentage of AGB was explored in the 15 plots, denoting greater loss of individuals due to mortality in the parcels with the highest intensity of exploitation.

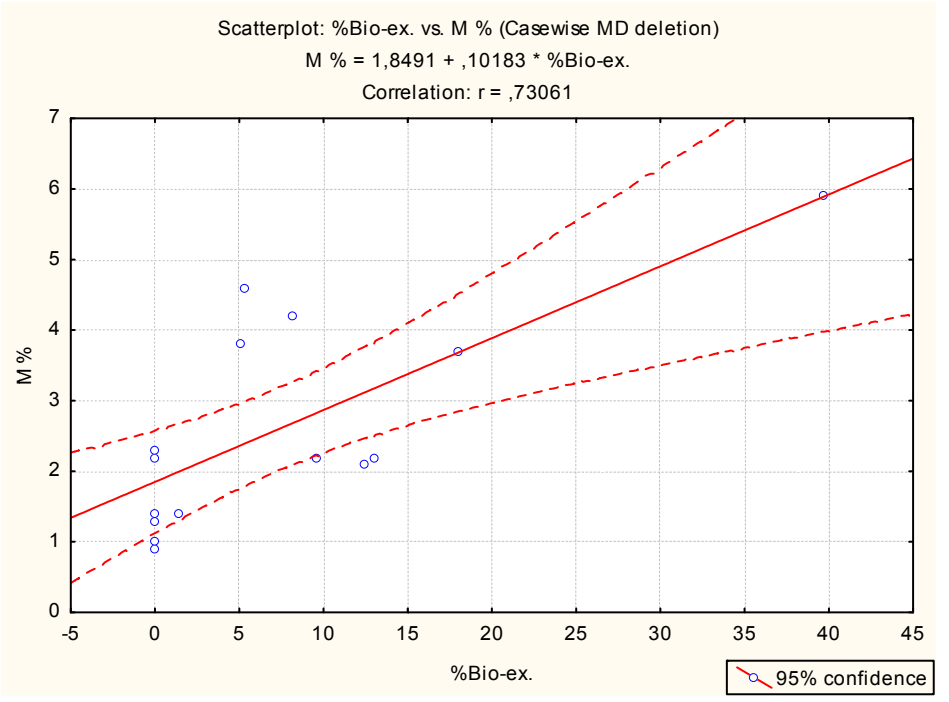

Figure 3. Correlation between mortality rate (M\%) and the percentage of AGB logged

The AGB in the parcels without RIL did not vary much over the years mortality rates remained balanced in rates of recruitment of new individuals (Table 1 and Figure 4A). In the plots the remaining AGB (rem) presented a significant variation, with a negative net balance for some exploited parcels, especially those with a shorter evaluation period (4 to 8 years). However, for the period (10 to 12 years), the remaining AGB values positive net balance, indicative of recovery of the initial inventories of AGB explored (Figure 4B). 

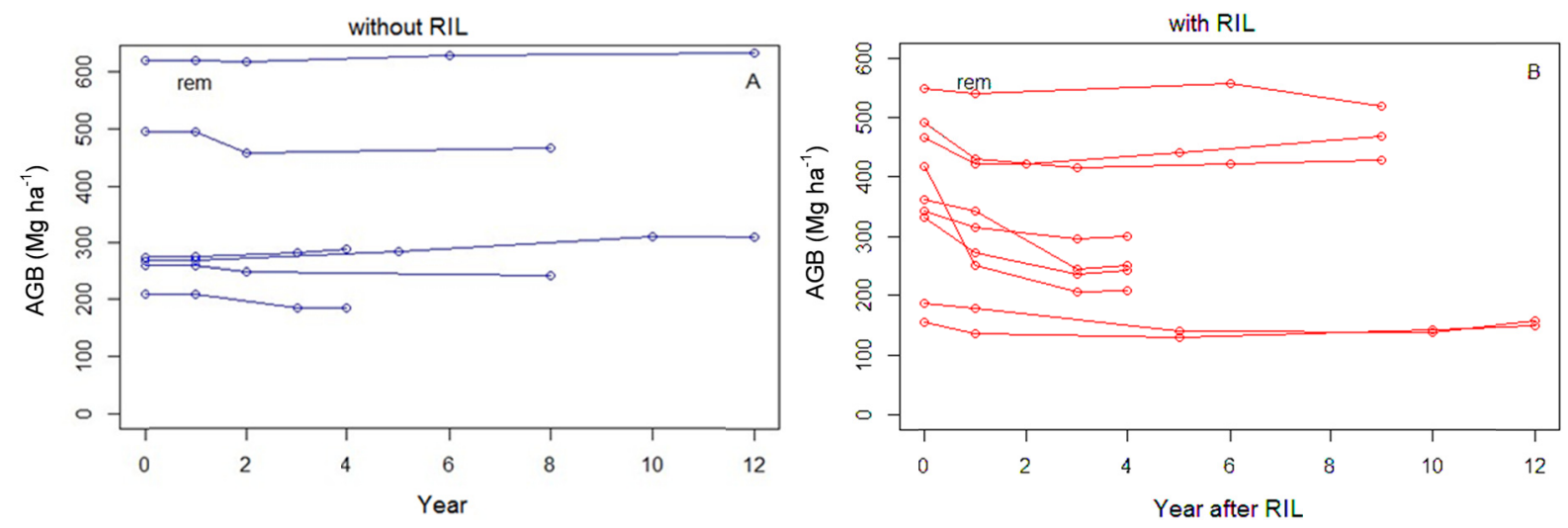

Figure 4. Evolution of AGB in 12 years, plots without RIL (A) and plots with RIL (B)

\section{Discussion}

With respect to initial biomass stocks, these values (Table 1) are close to those expected for the Amazon, in comparison with other biomass studies in the region and in other tropical forests on the planet. For example, in Alto Rio Negro, Amazonas, Lima et al. (2012) estimated inventories of AGB with values of approximately 253 $\mathrm{Mg} \mathrm{ha}^{-1}$. In the eastern Amazon, Mazzei et al. (2010) found an average of $410 \mathrm{Mg} \mathrm{ha}^{-1}$ of AGB. Sist et al. (2014) estimated values of biomass around $378 \mathrm{Mg} \mathrm{ha}^{-1}$ in Paragominas/Pará. West et al. (2014) found values close to $260 \mathrm{Mg} \mathrm{ha}{ }^{-1}$ and Vidal et al. (2016) estimated $237 \mathrm{Mg} \mathrm{ha}^{-1}$ both in the Eastern Amazon.

In French Guiana, Rutishauser et al. (2010) estimated the AGB of 395-443 $\mathrm{Mg} \mathrm{ha}^{-1}$. On the African continent, Gourlet-Fleury et al. (2013) found estimated values of $374.5 \mathrm{Mg} \mathrm{ha}^{-1}$ of AGB and Medjibe et al. (2011) found around $420 \mathrm{Mg} \mathrm{ha}^{-1}$ of AGB inventories. Still in Table 1, the amount of biomass lost by the 7.6 to $166 \mathrm{Mg} \mathrm{ha}^{-1}$.

The lack of geographic control and better distribution of the forest exploitation in the UTs of the management leads to the excess of harvest in certain places, with the formation of great clearings within the area of management, which should be avoided. In most of the plots, mortality rates exceeded the recruitment rates of new individuals (with diameter $\geq 10 \mathrm{~cm}$ ) in the forest, reaching $5.9 \%$ mortality of the trees in the P-14 plot at the end of the monitoring. In our data, we found a total of 19 trees above the limit diameter $(\leq 156 \mathrm{~cm})$ for the calculation of AGB by the local equation of Lima (2015). The P-08 plot had 05 individuals of this size.

The biomass values for trees above the diametric range (DBH $\geq 156 \mathrm{~cm}$ ) of the Lima model (2015) were estimated by extrapolation according to methodology used by West et al. (2014). Some authors, Mazzei et al. (2010) and Sist et al. (2014), preferred to replace the larger individuals by the maximum of the scope, which can reduce drastically the estimated values of AGB when having a high number of large trees, as noted in the Jari Florestal area.

The excess mortality observed in the trees with DBH $>60 \mathrm{~cm}$ had a contribution to the sharp decline in biomass four years after the exploration, a fact that may be directly influencing the recovery of the parcels evaluated. High mortality rates of large trees (>60 cm DBH) may reflect the negative recovery balance of biomass (Sist et al., 2014). The high mortality rate may occur in of a single large tree. On the other hand, the opening of clearings and light from the fall of large trees favors the recruitment of new individuals who were under the shadow of large trees (D’Oliveira \& Braz, 2006).

In the study area, large trees accounted for $55 \%$ of the total AGB of the parcels. In research in the eastern Amazon, West et al. (2014) reported that before the low-impact operation, 29\% of AGB was stored in trees of class $>60 \mathrm{~cm}$ in diameter. Sist et al. (2014) observed that large $(\mathrm{DBH}>60 \mathrm{~cm})$ represented $9.3 \%$ of tree density $\left(18 \pm 4\right.$ trees $^{-1} \mathrm{a}^{-1}$ ) but averaged $49 \%$ of total AGB, these large trees average $183 \mathrm{Mg} \mathrm{ha}^{-1}$, which represents almost $50 \%$ of the total biomass found initially, due to the abundance of very large trees with DBH $>100 \mathrm{~cm}$ and the dominance of tree species with high wood density.

In the eastern Amazon, Mazzei et al. (2010) found values of AGB immediately converted into harvested necromass (harvested trees and destroyed) averaged $94.5 \mathrm{Mg} \mathrm{ha}^{-1}$ or $23 \%$ of AGB before harvest. The high mortality rates in the study area are related to the variation in the amount of biomass harvested between the plots observed. Some parcels suffered large losses due to the high intensity of local exploitation, while other lots few trees were harvested and some plots showed no trees explored. 
In a study in the eastern Amazon, the use of RIL techniques reduced substantially the effect of the selective cut on the residual AGB, favoring the increase of AGB recovered over the 16 years, the average annual increments in AGB (recruitment + residual growth of trees minus the mortality) were $2.8 \mathrm{Mg} \mathrm{ha}^{-1}$ year $^{-1}$ in the RIL plots (West et al., 2014). On the other hand, in French Guiana, all 36 lots operated in a conventional system (without RIL) remained as sources of above ground emissions for 10 to 12 years following (Blanc et al., 2009).

In the monitored area, the majority of the plots with 4 to 8 years are suffering from losses of AGB, besides the biomass lost with the harvest, by the AGB lost by the RIL and associated damages. In research in the Eastern Amazon, after 20 years of monitoring a managed forest, Vidal et al. (2016) reported that the volumes of wood of large trees $(\geq 50 \mathrm{~cm} \mathrm{DBH})$ were recovered in $81 \%$ of the plots with RIL and the use of RIL techniques accelerated biomass recovery rates.

In the 15 plots studied in the Jari Florestal area, the plots with the longest evaluation period, approximately 12 years, showed a good development in AGB after the exploration, mainly due to the low intensity of local exploitation of these plots and the longer monitoring time in relation to other plots. According to Sist et al. (2014), to promote an operating intensity of 03 trees ha ${ }^{-1}$ would reduce $\mathrm{CO}_{2}$ emissions during the exploration and recover the initial biomass in a 35 -year cycle, established by Brazilian legislation, in addition, considering that DBH trees $>60 \mathrm{~cm}$ abduct on average $53 \mathrm{~kg} \mathrm{C}$ year $^{-1}$ due to growth, 03 trees would hijack an amount of $5.5 \mathrm{Mg}$ $\mathrm{C}$ ha $^{-1}$ over of a 35 -year cutting cycle.

Martin et al. (2015) suggest that further evidence is needed to assess the differences between the impacts of RIL and conventional logging. Restrict the logging intensity is essential, both from the growth point of view and survival of remaining trees (future crops) and also to the ecological sustainability of forest (Sist et al., 2003; Mazzei et al., 2010; Putz et al., 2012; Sist et al., 2005). An efficient way to improve the carbon balance in tropical rainforest production could be the preservation of large trees, individuals with DBH $>100 \mathrm{~cm}$ (Sist et al., 2014).

\section{Conclusion}

The analysis showed that the forest can that the forest can recover its initial stocks of AGB in 12 years after the RIL, in places with low intensity of exploitation. In with high cutting intensity, in the following years after RIL the forest continued to lose biomass, in addition to the trees removed, due to damage and mortality of the remaining trees.

Biomass studies in managed tropical forests are important and more knowledge must be produced to strengthen policies and incentives to forest management and RIL techniques, which conserve standing forests and maintain carbon stocks in forest biomass, thus contributing to the reduction of greenhouse gases emissions to the atmosphere and the balance of the climate on the planet.

\section{Acknowledgements}

In the field, we had full support of Jari Company staff and particularly want to thank Jussian for his extensive collaboration. We had the support of FRMBrasil Company providing the data for the research. Finally, we are very grateful to José Alipio, Tapiaca, Adjalma Souza, Ravani, Vânia and Paloma Caldas.

\section{References}

Blanc, L., Echard, M., Herault, B., Bonal, D., Marcon, E., Baraloto, C., \& Chave, J. (2009). Carbon stocks Dynamics of aboveground in a selectively logged tropical forest. Ecological Applications, 19(6), 1397-1404. https://doi.org/10.1890/08-1572.1

Brasil. (2009). Resolução Conama $n^{\circ}$ 406, de 02 de fevereiro de 2009 (p. 100). Publicado no DOU $\mathrm{n}^{\mathrm{o}} 26$, de 06/02/2009. Retrieved from http://www.mma.gov.br/port/conama/res/res09/res40609.pdf

Braz, E. M., Mattos, P. P., Thaines, F., Madron, L. D., Garrastazu, M. C., Canetti, A., \& D'Oliveira, M. V. N. (2015). Criteria to be considered to achieve a sustainable second cycle in Amazon Forest. Pesquisa Florestal Brasileira, Brasilia, 35(83), 209-225. https://doi-org/10.4336/2015.pfb.35.83.941.

D’Oliveira, M. V. N., \& Braz, E. M. (2006). Estudo da dinâmica da floresta manejada no projeto de manejo florestal comunitário do PC Pedro Peixoto na Amazônia Ocidental. Acta Amazonica, 36(2), 177-182. https://doi.org/10.1590/S0044-59672006000200007

Fox, J. C., Yosi, C. K., Nimiago, P., Oavika, F., Pokana, J. N., Lavong, K., \& Keenan, R. J. (2010). Assessment of Aboveground Carbon in Primary and Selectively Harvested Tropical Forest in Papua New Guinea. Biotropica, 42(4), 410-419. https://doi.org/10.1111/j.1744-7429.2009.00617.x 
Gourlet-Fleury, S., Mortier, F., Fayolle, A., Baya, F., Ouédraogo, D., Bénédet, F., \& Picard, N. (2010). Tropical forest recovery from logging: A 24 year silvicultural experiment from Central Africa. Philosophical Transactions, 368(1625), 1-10. https://doi.org/10.1098/rstb.2012.0302

IBGE (Instituto Brasileiro de Geografia e Estatística). (2012). Manual técnico da vegetação brasileira (Manuais Técnicos em Geociências). IBGE, Rio de Janeiro, Rio de Janeiro, Brazil. Retrieved from https://biblioteca. ibge.gov.br/visualizacao/livros/liv63011.pdf

Imai, N., Samejima, H., Langner, A., Ong, R. C., Kita, S., Titin, J., ... Kitayama, K. (2009). Co-benefits of sustainable forest management in biodiversity conservation and carbon sequestration. PLoS One, 4(12), e8267. https://doi.org/10.1371/journal.pone.0008267

Jari, F. (2014). Plano de manejo Florestal Sustentável (Resumo Público). Monte Dourado-PA. Retrieved from http://www.grupojari.com.br/florestal

Johns, J. S., Barreto, P., \& Christopher, U. (1996). Logging damage during planned and unplanned logging operations in the eastern Amazon. Forest Ecology and Management, 89(1-3), 59-77. https://doi.org/10. 1016/S0378-1127(96)03869-8

Lima, A. J. N., Suwa, R., Mello Ribeiro, G. H. P., Kajimoto, T., Santos, J., Silva, R. P., ... Higuchi, N. (2012). Allometric models for estimating above and below-ground biomass in Amazonian forests at São Gabriel da Cachoeira in the upper Rio Negro, Brazil. Forest Ecology and Management, 277, 163-172. https://doi.org/ 10.1016/j.foreco.2012.04.028

Lima, R. C. (2015). Equações para estimativas de biomassa de uma floresta tropical úmida do Amapá (49f., Dissertação (Mestrado em Ciências Florestais), Universidade Federal Rural de Pernambuco, Recife). Retrieved from http://www.ppgcf.ufrpe.br/sites/www.ppgcf.ufrpe.br

Martin, P. A., Newton, A. C., Pfeifer, M., Khoo, M., \& Bullock, J. M. (2015). Impacts of tropical selective logging on carbon storage and tree species richness: A meta-analysis. Forest Ecology and Management, 356 , 224-233. https://doi.org/10.1016/j.foreco.2015.07.010

Mazzei, L., Sist, P., Ruschel, A., Putz, F. E., Marco, P., Pena, W., \& Ferreira, J. E. R. (2010). Above-ground biomass dynamics after reduced-impact logging in the Eastern Amazon. Forest Ecology and Management, 259(3), 367-373. https://doi.org/10.1016/j.foreco.2009.10.031

Medjibe, V. P., Putz, F. E., Starkey, M. P., Ndouna, A. A., \& Memiaghe, H. R. (2011). Impacts of selective logging on above-ground forest biomass in the Monts de Cristal in Gabon. Forest Ecology and Management, 262(9), 1799-1806. https://doi.org/10.1016/j.foreco.2011.07.014

Miller, D. S., Goulden, M. L., Hutyra, L. R., Keller, M., Saleska, S. R., Wofsy, S. C., ... Camargo, P. B. (2011). Reduced impact logging minimally alters tropical rainforest carbon and energy exchange. PNAS, 108(48), 19431-19435. https://doi.org/10.1073 / pnas.1105068108

Nogueira, E. M., Fearnside, P. M., Nelson, B. W., Barbosa, R. I., \& Keizer, E. W. H. (2008). Estimates of forest biomass in the Brazilian Amazon: New allometric equations and adjustments to biomass from wood-volume inventories. Forest Ecology and Management, 256(11), 1853-1867. https://doi.org/10.1016/j.foreco. 2004.12.007

Orsa, F. (2009). Plano de manejo florestal sustentável Orsa Florestal S.A., 2009. Retrieved from http://www.grupojari.com.br/florestal

Piponiot, C., Sist, P., Mazzei, L., Peña-Claros, M., Putz, F. E., Rutishauser, E., ... Hérault, B. (2016). Carbon recovery dynamics following disturbance by selective logging in Amazonian forests. eLIFE, 5(e21394), 1-19. https://doi.org/10.7554/eLife.21394

Putz, F. E., Zuidema, P. A., Synnott, T., Peña-Claros, M., Pinard, M. A., Sheil, D., ... Zagt, R. (2012). Sustaining conservation values in selectively logged tropical forests: the attained and the attainable. Conservation Letters, 5(4), 296-303. https://doi.org/10.1111/j.1755-263X.2012.00242.x

R Development Core Team. (2018). R: A language and environment for statistical computinging. R Foundation for Statistical Computing, Vienna, Austria. Retrieved from https://www.r-project.org/

Rocha, K. J., Souza, E. C. S., Favalessa, C. M. C., Caldeira, S. F., Martinez, D. T., \& Brondani, G. B. (2017). Effect of selective logging on floristic and structural composition in a forest fragment from Amazon Biome. Acta Scientiarum, 39(2), 191-199. https://doi.org/10.4025/actasciagron.v39i2.32543 
Rutishauser, E., Wagner, F., Herault, B., Nicolini, E., \& Blanc, L. (2010). Contrasting above-ground biomass balance in a Neotropical rain forest. Journal of Vegetation Science, 21(4), 672-682. https://doi.org/10.1111/ j.1654-1103.2010.01175.x

SFB (Serviço Florestal Brasileiro) \& IPAM (Instituto De Pesquisa Ambiental Da Amazônia). (2011). Florestas Nativas de Produção Brasileiras (Relatório). Brasília, DF. Retrieved from http://www.florestal.gov.br/snif

Sheil, D., Burslem, D. F. R. P., \& Alder, D. (1995). The interpretation and misinterpretation of mortality rate measures. Journal of Ecology, 83(2), 331-333. https://doi.org/10.2307/2261571

Sist, P., \& Ferreira, F. N. (2007). Sustainability of reduced-impact logging in the Eastern Amazon. Forest Ecology and Management, 243(2-3), 199-209. https://doi.org/10.1016/j.foreco.2007.02.014

Sist, P., Mazzei, L., Blanc, L., \& Rutishauser, E. (2014). Large trees as key elements of carbon storage and dynamics after selective logging in the Eastern Amazon. Forest Ecology and Management, 318, 103-109. https://doi.org/10.1016/j.foreco.2014.01.005

Sist, P., Rutishauser, E., Peña-Claros, M., Shenkin, A., Hérault, B., ... Yamada, T. (2015). The Tropical managed Forests Observatory: A research network addressing the future of tropical logged forests. Applied Vegetation Science, 18(1), 171-174. https://doi.org/10.1111/avsc.12125

Sist, P., Sheil, D., Kartawinata, K., \& Priyadi, H. (2003). Reduced-impact logging in Indonesian Borneo: Some results confirming the need for new silvicultural prescriptions. Forest Ecology and Management, 179, 415-427. https://doi.org/10.1016/S0378-1127(02)00533-9

Souza, A. L., Medeiros, R. M., Matos, L. M. S. L., Silva, K. R., Corrêa, P. A., \& Faria, F. N. (2014). Estratificação volumétrica por classes de estoque em uma floresta ombrófila densa, no município de Almeirim, Estado do Pará, Brasil. Revista Árvore, 38(3), 533-541. https://doi.org/10.1590/S0100-67622014 000300016

Ter Steege, H., Pitman, N. C. A., Sabatier, D., Baraloto, C., Salomão, R. P., Guevara, J. E., ... Silman, M. R. (2013). Hyperdominance in the Amazonian Tree Flora. Science, 342(6156), 324-334. https://doi-org/ $10.1126 /$ science. 1243092

Vidal, E., West, T. A. P., \& Putz, F. E. (2016). Recovery of biomass and merchantable timber volumes twenty years after conventional and reduced-impact logging in Amazonian Brazil. Forest Ecology and Management, 376, 1-8. https://doi.org/10.1016/j.foreco.2016.06.003

West, T. A. P., Vidal, E., \& Putz, F. E. (2014). Forest biomass recovery after conventional and reduced-impact logging in Amazonian Brazil. Forest Ecology and Management, 314, 59-63. https://doi.org/10.1016/j.foreco. 2013.11.022

Zimmerman, B. L., \& Kormos, C. F. (2012). Prospects for sustainable logging in tropical forests. BioScience, 62(5), 479-487. https://doi.org/10.1525/bio.2012.62.5.9

\section{Copyrights}

Copyright for this article is retained by the author(s), with first publication rights granted to the journal.

This is an open-access article distributed under the terms and conditions of the Creative Commons Attribution license (http://creativecommons.org/licenses/by/4.0/). 